\title{
Temaet folkemord i forfatterskapet til Tore Linné Eriksen
}

Randi Rønning Balsvik

Universitetet i Troms $\varnothing$ - Norges arktiske universitet

randi.balsvik@uit.no

\author{
Keywords \\ Tore Linné Eriksen \\ Genocide studies \\ Historiography \\ Colonialism \\ Namibia
}




\begin{abstract}
This article points to the responsibility historians have in the formation of what we may call the collective memory of persons, groups and states. What are the images of "the other" conveyed in textbooks and media? In Norway, the historian Tore Linné Eriksen has - more than any other scholar - used his research, writings and enormous capacity for work to educate students, youth and the public in general and to create a more just image of "the other". His driving force has been an extraordinary ability to be at the forefront in spotting international research, as well as his sense of justice and respect for the non-western world. His last extensive work on global history (Globalhistorie 1750-1900) clearly demonstrates these capabilities.
\end{abstract}

In the early 1980s, long before the wave of genocide studies after the Rwanda catastrophe of 1994, Eriksen's two works on Namibia - Namibia: Kolonialisme, apartheid og frigjøringskamp $i$ det sørlige Afrika (1982) and The Political Economy of Namibia: An Annotated Critical Bibliography (1985) - used the concept of genocide to describe German conduct in Namibia in the early 20th century. In 2007, Eriksen published his book about what he calls the first genocide of the 20th century, Det første folkemordet $i$ det tjuende arhundret. Namibia 1903-1908. German and African history is woven into the question of whether the dangerous relations that developed between German settlers and Africans can be labelled genocide. The present article attempts to present Eriksen's arguments. An introductory section deals with the trends in the international research literature and establishes a link between colonialism and genocide. In 2008, Eriksen's article on the extinction of the Herero people in Namibia - "Utslettelse av Hererofolket i Namibia 19031908" - was published in Bernt Hagtvets collection of articles, Folkemordenes svarte bok. The following year, Tore Linné Eriksen's article in the journal Historisk Tidsskrift (2009) on genocide in a comparative colonial perspective won the prize for best article of the year.

In Eriksen's global history, referred to above, it is stated and shown that, to a certain extent, there is disagreement among historians as to what can be called genocide. What about the extinction of indigenous peoples due to diseases in the wake of European immigration? In his use of the term, Eriksen is more cautious than the authors of some of the works he refers to. The present article argues for more attention to be paid to the concept of "intent" when it comes to interpreting the tragic outcomes of conflict. 
Det er historikeres ansvar å bidra til å forme det kollektive minnet. Hva skal vi huske av fortida, hvordan forvalte ettermælet til enkeltpersoner, grupper og stater? Det som kan få plass i lærebøker og andre former for produksjon for unge mennesker har stor betydning i en verden der alle stater og folkeslag er kommet stadig nærmere hverandre. Hvordan er vår framstilling av "de andre", velkjent fra orientalismedebatten etter Edvard Saids forfatterskap? Det som står på spill er det bildet som framkommer av "de andre", identiteten til den verden som langt senere kom i gang med det moderniserende teknologiske gjennombruddet, og bildet av oss selv, det Europa som i en kort tidsperiode har dominert og høvlet over verden.

Den politiske venstresidas sterke plass innenfor akademia, særlig sprunget ut av de skjellsettende og rystende inntrykkene fra USAs krigføring i Vietnam, etablerte en tradisjon av sterk kritikk av vestlig imperialisme og maktutfoldelse. Tore Linné Eriksen er uten tvil den norske historikeren som i størst grad har brukt sin forskning, historieskrivning, skribentvirksomhet, sin enorme arbeidskapasitet til folkeopplysning i "de andres" tjeneste. Drivkraften har vært en uvanlig engasjert rettferdighetssans og respekt for den ikkevestlige verden. Gjennomgående representerer Tores siste store verk, Globalhistorie 1750 1900 fra 2010, en sterk oppvurdering av "de andres" nivå av utvikling før møtet med Europa og europeisk intervensjon og det bildet som den gang ble formidlet. Globalhistorien er et angrep på inngrodde ryggmargsreflekser når det gjelder oppfatningen om vestens overlegenhet i utvikling. Tore Iøfter fram fortjenesten til andre kulturer. Særlig gjelder det for India, Kina og Japan.

Tore er alltid tidlig ute, ligger foran de fleste når det gjelder å ta inn over seg og videreformidle hva som rører seg i internasjonal fagdebatt. Antologien Det politiske universitet kom allerede i 1969. Der ble det satt fokus på studentene som fortropp i den internasjonale klassekampen. I 1974 kom antologien Underutvikling med det som alltid er Tores varemerke: mange tettskrevne sider med faglitteratur omkring emnet, hentet fra flere språk under overskriften "noen forslag til videre lesning". Han har et skarpt blikk for hva utviklingen, særlig i betydningen økonomisk vekst, har kostet, og den prisen som er betalt av den ikke-vestlige verden. Den prisen som mitt innlegg skal dreie seg om er fenomenet folkemord. Jeg vil se på hvordan det framkommer i Tores 500 siders lærebok, den omtalte globalhistorien, og også i hans omfattende historiografiske artikkel i Historisk Tidsskrift (2009): "Folkemord i et komparativt koloniperspektiv: et riss av en fagdebatt." For den fikk han tidsskriftets pris for beste artikkel i 2009.

En fordypning i temaet folkemord var delvis en følge av invitasjonen til Bernt Hagtvet om à bidra med et kapittel i Folkemordenes svarte bok, der Tore tok for seg det første folkemordet i det tjuende århundre, i Namibia. Han ble spurt, sannsynligvis fordi han hadde arbeidet med Namibias historie tidligere. Namibia: Kolonialisme, apartheid og frigjøringskamp i det sørlige Afrika kom i 1982 og publikasjonen The political economy of Namibia. An annotated critical bibliography i 1985. Allerede tidlig på 1980-tallet, før den store bølgen av folkemordstudier, bruker Tore begrepene folkemord og genocide om tysk framferd i Namibia.

Tores arbeid med kapittelet i Svarteboka svulmet opp og ble til utgivelsen av en monografi, Det første folkemordet $i$ det tjuende arhundret. Namibia 1903-1908, som kom ut i 2007, året før Hagtvets bok om folkemordene. Tores bok er en studie der afrikansk og tysk historie er innvevd i problemstillingen om hvorvidt relasjonen mellom innvandrede tyskere og afrikanere, som utviklet seg katastrofalt for overlevelsen av et helt folk, kunne sies å være et folkemord. Med denne studien bidrar Tore til den internasjonale trenden å løsrive forestillingene våre om at folkemord er reservert for det ene grufulle, unike holocaust av jødene under det tyske naziregimet. Med sin overlegne evne til å oppspore og ikke minst 
tilegne seg nyere internasjonal forskningslitteratur, viser han hvordan begrepet folkemord er blitt utvidet og brukt om europeeres innvandring og okkupasjon i verden utenfor Europa. Definisjonen av folkemord i FNs folkemordskonvensjon av 1948 inkluderer ikke virkningene av krigføring, men Tore har vist hvordan den nye internasjonale strømmen av folkemordstudier har brukt karakteristikken "folkemord" på den massedød som ofte ble en følge av europeeres ekspansjon i verden. Den nye bølgen av oppmerksomhet har i noen grad vært inspirert av behovet for å forstå folkemordet i Rwanda. Etter år 2000 har det kommet egne tidsskrift og en lang rekke enkeltstudier og samleverk. Med boken om folkemordet i Namibia med dens innledende historiografi, har Tore definitivt etablert forbindelsen mellom folkemord og kolonialisme. Den siste utgaven av Jarle Simensens Afrikas historie fra 2009 har på markert vis integrert Tores forskning om Namibia. Dette er betydningsfullt fordi Simensens bok er den mest brukte for afrikastudier i høyere undervisning her i landet.

Da de europeiske stormaktene tildelte hverandre kolonier i Afrika i Berlin i 1885, fikk Tyskland bl.a. det området som kom til å bli kalt Tysk Sørvest- Afrika som interessesfære, et område der tyske misjonærer og handels- og gruvedriftsinteresser allerede sto for en viss virksomhet. Etter første verdenskrig ble Tyskland fratatt sine kolonier og området ble gitt som mandat til Storbritannia av Folkeforbundet, som igjen overlot det til sørafrikansk styre. Først i 1990 oppnådde frigjøringsbevegelsene uavhengighet og landet fikk navnet Namibia.

Hva det var som førte fram til katastrofen, i dette tilfelle i Namibia, er et hovedspørsmål i all forskning om mulig folkemord. Tores framstilling har en stor rikdom på dokumenterte detaljer og vurderinger om hva som foregikk både på afrikansk og europeisk side og $\mathrm{i}$ samhandlingen mellom partene, som gjør boken til svært spennende lesning. Tyskland ville skape en bosettingskoloni for tyske bønder og handelsmenn. I noen få tilfeller kom det utover i 1890-tallet i stand avtaler med afrikanske ledere som fikk store fordeler ved å samarbeide med kolonimakten og med misjonærer. Tyskerne stanget imidlertid hodet $\mathrm{i}$ veggen, fordi det ikke var noen tradisjon for å selge verken jord eller kveg. Tyskerne brukte imidlertid alle midler til å overta nama- og hererofolkets jord og kveg og ville, til å begynne med, ha den afrikanske befolkningen inn i reservater. Misjonærer ivret for dette for à sikre at afrikanere fikk beholde noe av sin jord. Hererolederen Samuel Maharero framholdt på sitt folks vegne at de foreslåtte reservatene var for små, hadde for dårlig jordsmonn og var for langt borte fra deres kjerneområder. En tysk administrator ønsket ikke videre forhandlinger, og forfalsket underskrifter som etablerte reservater folk ikke ville ha. Han begikk overtramp som gjorde at han ble kalt hjem.

Det oppsto krigslignende tilstander i januar 1904. Hererofolk ødela og erobret gårder med tusentalls dyr og drepte 130 tyskere. Den mer forhandlingsinnstilte Leutwein, som hadde vært tysk guvernør i ti år, ble fratatt sin militære kommando og ble senere avsatt som guvernør. General von Trotha ble sendt av keiseren og generalstaben i Tyskland til å lede 5000 tyske soldater for avgjørende å slå ned motstanden mot tysk virksomhet. Det skulle skje med moderne maskingevær og kanoner. Von Trothas strategi var omringning og et stort slag mot ca 6-7000 langt dårligere bevæpnete stridende hereroer, som hadde forflyttet og samlet seg rundt Waterberg sammen med store deler av sitt folk. Beregninger går ut på at herero befolkningen talte ca 70000 og at ca 50000 var samlet her. 11. august startet det store "Hamakari-slaget", som varte i to dager med en nådeløs nedslakting av stridende, så vel som kvinner og barn. Parolen var at det ikke skulle tas krigsfanger. Henrettelser var eneste alternativ. Spørsmålet om å tillate overgivelse ble ikke reist. Det var en nokså vanlig europeisk oppfatning at krigens folkerett var reservert bare for "siviliserte" folkeslag. Antall døde i løpet av de to dagene er anslătt til $20-30000$. Tusener av hereroer klarte à bryte gjennom den tyske innringningen og flyktet innover det karrige landskapet $\mathrm{i}$ 
retning av Kalahariørkenen og Botswana. Et par tusen kom kanskje over grensen, resten ble forfulgt av tyske soldater fra vannhull til vannhull til de omkom av sult og tørst. Fram til 1908 var to-tredjedeler av hererobefolkningen utryddet. De som ikke Hamakari-slaget og den påfølgende forfølgelsen klarte å avlive, bukket under i konsentrasjons- og slavearbeidsleire, utsatt for ekstrem mishandling og elendige livsvilkår. Leirene omfattet hele herero- og namabefolkningen, uansett alder og kjønn.

Tores bok er en studie av historieforskningen omkring de hendelsene som er referert her. En gjennomgående problemstilling er spørsmålet om det som hendte kan kalles et folkemord, noe teksten i flere ulike sammenhenger slår fast at det hersker det liten tvil om. Det er utviklingen etter Hamakari-slaget, den grufulle forfølgelsen og konsentrasjonsleirene som blottlegger en bevisst hensikt om utryddelse av et helt folk.

Bibliografien til Tores bok, på mer enn 17 sider, levner ikke tvil om at folkemord er blitt et framtredende tema innenfor forskningen i løpet av det siste tiåret. Hundreårsmarkeringen for Hamakari-slaget frambrakte mange arbeider, ikke minst fra tyske forskere. Spørsmålet om hvordan krigen oppsto, er sagt å være det historiografisk sett mest kontroversielle. Ny forskning framstiller det mye mer nyansert og komplisert enn den versjonen som er den vanlige i tidligere historiske framstillinger, nemlig at den tyske aksjonen kom som et svar på et godt planlagt og samlet opprør mot kolonimakten fra hererofolkets side. Riksdagen ønsket å sende en kommisjon for å oppklare nettopp dette spørsmålet, men en slik undersøkelse ble stanset av den tyske keiseren. Så det finnes ingen offisiell tysk versjon om selve krigsutbruddet.

Hererosamfunnet var i krise etter den omfattende kvegpesten som herjet store deler av Afrika fra tidlig på 1890-tallet. Den spesielle nødssituasjonen som også innbefattet tørkeår og gjeldskrise, gjorde det lettere for tyske innvandrere å overta jord og kveg fra den afrikanske befolkningen. Ut fra tidligere lite brukt arkivmateriale har forskning kommet fram til at de første trefningene i det som ledet fram til krigen, kom mer som følge av de tyske bosetternes forestillinger, krigsfrykt og aggressive mentalitet i forhold til hereroene enn en planlagt, samlet oppstand fra hererofolkets side. Guvernør Leutwein hadde mottatt en strøm av henvendelser fra misfornøyde tyskere som krevde at den afrikanske befolkningen ble satt ettertrykkelig på plass. Leutweins holdning ble sett på som altfor ettergivende og uakseptabelt innstilt på forhandlinger. Guvernøren argumenterte for at kolonien trengte hereroene som arbeidskraft.

Hvordan krigen kunne få slike katastrofale følger, er et spørsmål som belyses fra mange synsvinkler og gis mange delforklaringer ut fra forskningslitteraturen. Diskusjonen handler om kjernespørsmål i den klassiske vurderingen av hva som kommer inn under betegnelsen folkemord - i hvilken utstrekning det kan sies at utryddelse, "Vernichtung", var bevisst planlagt fra tysk side, eller i hvilken utstrekning den ble en følge av omstendighetene i løpet av krigens gang. I denne sammenhengen legges det stor vekt på holdningene og disposisjonene til den offiseren som den tyske keiseren sendte ut for å lede de tyske troppene. Ved avsettelsen av Leutwein og sterk irettesettelse av misjonærenes fors $ø \mathrm{k}$ på å fremme afrikanske interesser, var det i utgangspunktet slått fast at det ikke var aktuelt å forhandle for å komme fram til kompromissløsninger i konflikten mellom hereroer og tyske bosettere.

Den keiserlig utvalgte øverstkommanderende von Trotha hadde en prøyssisk aristokratisk militær bakgrunn og en lang og velkjent karriere i krigsinnsats for Tyskland, mot Østerrike og Frankrike i årene 1866 og 1870/71, i Kina under "bokseropprøret" omkring 1900 og ikke minst var han kjent som den nådeløse og brutale kommandanten i Tysk Øst-Afrika under nedkjempingen av hehefolket midt på 1890-tallet. For denne mannen var eneste målsetting total seier på slagmarken for de tyske troppene. Han var i pakt med tysk nasjonalismes 
kamp for Weltmacht og med keiserens brautende ambisjoner. I ikke liten utstrekning leverte han det som var bestilt.

Etter en feltgudstjeneste 2. oktober 1904 sendte von Trotha ut en erklæring til hereroene som har fatt stor oppmerksomhet $i$ nyere forskning, særlig sett $i$ sammenheng med spørsmålet om graden av intensjonalitet $i$ tysk strategi, som har vært viktig for à kunne bruke kategoriseringen "folkemord". Erklæringen er omtalt som Vernichtungsbefehl, selv om ordet ikke er brukt $i$ det som "Jeg, den store general til den mektige tyske keiser" framførte som budskap til fienden (Eriksen 2007, s. 90). Det navngir hereroene og sier at alle inkludert kvinner og barn vil bli fordrevet fra kolonien eller skutt. Noen uker etter sendte von Trotha brev til guvernøren der han uttalte at hereroene som nasjon matte knekkes for aldri \& kunne gjøre et nytt opprør. Her brukes ordet vernichtet. Von Trotha oppsummerer sine intensjoner slik:

The exercise of violence with crass terrorism and even with gruesomeness was and is my policy. I destroy the African tribes with streams of blood and streams of money. Only following the cleansing can something new emerge, which will remain. (ibid., s. 94)

Dagbøker og memoarlitteratur etter tyske offiserer forteller at de handlet etter ordre om å tilintetgjøre en hel stamme og at ikke noe liv skulle bli spart.

Strategien krevde et utvetydig knusende nederlag som de tyske styrkene ikke oppnådde. Hereroene opptrådte uventet sterkt og samlet, og grupperinger kom seg unna. Forfølgelsene inn i det tørre landskapet var ikke minst krevende for de tyske soldatene som led store tap, også på grunn av uvante sykdommer og omgivelser. I følge offisielle tall mistet 1633 tyske soldater livet i årene 1903-8. Historikerne legger stor vekt på at slik krigen utviklet seg, kunne den representere et tap av militær ære, et tap i forhold til de tyske aspirasjonene om "Weltmacht" og som vi skal omtale nærmere nedenfor, et tap i forhold til usvikelig tro på at de var et overlegent herrefolk, en sivilisasjonsmakt som underla seg barbarene. Forskningsarbeid om tysk militær kultur, oppfatninger av verden og praksis i krig, får en framtredende plass i de historiografiske fortolkningene. Den aristokratisk, militaristiske prøyssiske kulturen anerkjente bare seier i krig og inkluderte i liten grad diplomati og forhandlinger $\mathrm{i}$ forholdet til fienden.

Tore har bidratt med brede framstillinger av den faglige diskusjonen omkring begreper folkemord og om den utvidelsen av begrepet som har skjedd $\mathrm{i}$ forhold til det jødiske holocaust. Et vanlig synspunkt har framkommet om at den jødiske tragedien har skyggelagt andre typer av overgrep mot store befolkningsgrupper. Den polske folkerettsjuristen Raphael Lemkin, regnes som opphavsmann til begrepet "genocide" og FN- konvensjonen om folkemord av 1948. Bakgrunnen for konvensjonen er naziregimets og den andre verdenskrigs utryddelse av jødene og andre folkegrupper. Konvensjonen legger vekt på at en intensjon må være til stede, en plan om å likvidere størstedelen av en bestemt folkegruppe, dersom begrepet folkemord skal kunne brukes i rettslig sammenheng.

Den nye forskningen reiser spørsmål ved om definisjonen i konvensjonen er for innsnevrende, at den var et politisk kompromiss mellom stormakter som hadde "klare interesser av å unngå søkelys mot mørkere sider ved egen historie" (Eriksen, 2007, s. 17). Lemkins store arkiv med etterlatte upubliserte arbeider viser at også han hadde et utvidet perspektiv. Han viste europeisk kolonialisme oppmerksomhet og fokuserte også på den europeiske ekspansjonens historie når det gjaldt utryddelse av urfolk. Tores historiografiske bidrag og globalhistorien etablerer hvordan dette utvidede perspektivet har fătt et stort fokus i forskningen: De største farene for folkemord lå i settler-kolonialismen, der store grupper europeere søkte en ny tilværelse på den andre siden av havene, enten det var i 
Sør- eller Nord Amerika, i Australia eller New Zealand. Møtet med den lokale befolkningen, med urfolket, som bruker jorda ekstensivt og i fellesskapsforvaltning, hindret nykommerne i å skaffe seg det de ville ha, egne gårder og egne husdyr: individuell privat eiendom.

I sin globalhistorie viser Tore at det er uenighet, en viss historikerstrid, om hva som kan regnes som folkemord, men at fordriving av urfolk og overgrep med teknisk overlegne våpen stadig oftere i den internasjonale faglitteraturen betegnes som folkemord (Eriksen, 2010 , s. 247). Det er antatt at 80 prosent av den opprinnelige befolkningen i Australia og New Zealand mistet livet som følge av forvisning, militære sammenstøt, sykdommer og underernæring i løpet av 1800-tallet. Samtidig var det nærmest utformet en doktrine om terra nullius, uberørt jord, om retten til å okkupere områder dersom befolkningen manglet begreper om privat eiendomsrett i europeisk forstand. I nyere forskning, stort sett etter 2000 , er det en tendens til at kolonisering og fordrivelse av urfolk som medfører massedød, betegnes som folkemord. Dette gjelder i aller høyeste grad tidlig europeisk ekspansjon i Sør-Amerika, der 80-90 prosent av urbefolkningen mistet livet ved plyndring, våpenmakt og sykdommer, "en av de største katastrofene i menneskehetens historie" (Eriksen, 2010, s. 265), men også i USA, der utviklingen blir benevnt som Nord Amerikas "skjulte holocaust" (ibid., s. 222,226,233). En ekstremversjon av dette er at det europeiske folkemordet på urfolk på det amerikanske kontinent er det største og mest ødeleggende gjennom alle tider (Eriksen, 2007, s. 20).

USA representerer altså på ingen måte et unntak. Ved lov og retningsgivning fra høyeste politiske hold i USA skjedde en systematisk fordriving og tvangsflytting av urbefolkningen og undergraving av deres livsgrunnlag. Her er virkningene av kompliserte langvarige prosesser med europeisk framrykking som førte til massedød omtalt som folkemord, selv om, som Hagtvet sier i sin innledning til Svarteboken, det bare var ekstremister som talte for, hadde en intensjon om, total utslettelse av indianerne. Men nyere forskning peker altså i retning av at nybyggerne som stadig trengte vestover på kontinentet, gjorde seg skyldig $\mathrm{i}$ folkemord. Virkninger av handlinger og av epidemier, tilsiktede eller utilsiktede er det som teller.

Det er stor forskjell på hva slags begreper historikere bruker på disse hendelsene i fortida. Om virkningene av europeisk framferd ble tragisk massedød eller folkemord er ikke likegyldig. Menneskehetens historie er full av folkevandringer og hærførere som underlegger seg imperier ut fra en overlegen våpenteknologi. Utvandringen til den nye verden hadde sin egen logikk ut fra den situasjonen mennesker i Europa opplevde at de sto i. Befolkningsøkning, mangel på dyrkbar jord og senere utelukkelse fra egne arbeidsmarkeder på grunn av den teknologiske utviklingen gjorde at millioner forlot Europa, tilskyndet av nye muligheter i sparsomt befolkede områder. Satt på spissen, kolonisasjon handlet stort sett alltid om at innvandrere tilranet seg andre folkeslags jord, med tragiske og dødbringende virkninger for den opprinnelige befolkningen. Hvordan skal dette benevnes? Innvandrerne var oftest enkeltindivider, enkeltfamilier, som neppe hadde intensjoner om å utrydde den opprinnelige befolkningen. Begrepene massedrap og folkemord impliserer kriminelle handlinger. Er den nye større bruken av begrepet en utvanning, en trivialisering i likhet med Hannah Arendts "banality of evil"? Får vi under gitte omstendigheter "the banality of genocide" der hvilken som helst av de europeiske folkeslag er på frammarsj. Hva vinner en historisk framstilling på å kalle virkingene av den europeiske inngripen på andre kontinenter for folkemord? Massedød blant lokalbefolkning var også i stor grad forårsaket av bakterier med påfølgende sykdomsepidemier som kom med innvandrerne. Den kunne også være forårsaket av inngripen i måten å dyrke jorda på, av plantasjedrift og avskoging, som forverret tørkeperioder og kunne føre til utilsiktet underernæring og sult. 
India har en forferdelig historie om massedød av titalls millioner under britisk styre. Innledningskapittelet til boken om Namibia viser til boken av Mike Davis med den talende tittelen Late Victorian holocausts (2000), der han viser britiske myndigheters direkte og indirekte medansvar for sultkatastrofer, "famines of genocide" med millioner av ofre i India i siste halvdel av 1800-tallet (Eriksen, 2007, s. 17-21). Årsakene lå i ideologien om "den passive stat" og den "utstrakte evnen til å overse den ikke-hvite befolkningens lidelser". Moralsk blir dette sagt å kunne sidestilles med å slippe bomber på befolkningen. Sultkatastrofer i forbindelse med uår og tørke i India under kolonistyret blir av andre omtalt som "famines of neglect". Kolonimyndighetene visste om natur- og sultkatastrofer, men prioriterte hæren og mateksporten til Storbritannia framfor nødhjelp. Globalhistorien viser i selve teksten til boktitler med benevnelsen "holocausts" (Eriksen, 2010, s. 390), men er forsiktig med bruken av "folkemord" i den norske teksten i alle de sammenhengene Tore skriver om massedød som virkninger av britisk politikk. Det framheves imidlertid i boken om tysk framferd i Namibia at det har vært påfallende lite fokus i forskningen på de mørkere sidene av britisk imperialisme (Eriksen, 2007, s. 185). Når forbindelsen mellom kolonialisme og folkemord nå er etablert, ligger det store utfordringer i å forske nærmere på virkningene av britisk politikk.

Innledningsvis skrev jeg at historikeren er med på å forme ettermæle og har et ansvar for å forstå mennesker ut fra sine egne forutsetninger, materielle så vel som mentale. Historikeren må bestrebe seg på å komme sannheten om fortida så nær som mulig, ut fra de perspektivene han/hun velger å fokusere på, men må ikke begå urett mot fortidas aktører, for eksempel europeiske innvandrere til USA, ved å framstå som en dommer. Derfor må bruken av begrepet folkemord være særdeles nøye overveid og ikke i for stor grad frakoples begrepet intensjonalitet. Massedødelighet i en befolkning på grunn av nye sykdomsbakterier og klimatiske svingninger burde ikke kvalifisere for innlemmelse i "folkemord"-stempelet.

Den aktivt inngripende stat er et produkt av en gradvis utvikling utover 1900-tallet. Statlig beredskap var minimalt utviklet og historikeres bedømming av deres manglende agering i fortida må ikke farges av det statlige ansvaret vi kjenner i dag. Kanskje mener jeg med

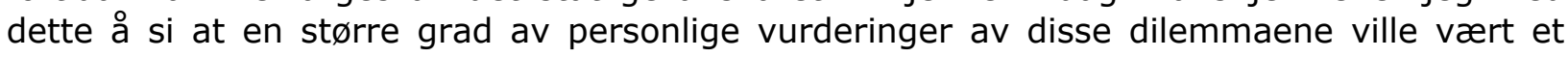
gode i Tores brede overblikk over forskningsfeltet.

Rasisme er framtredende i vurderingene av de faktorene som gjorde folkemordet i Namibia mulig (Eriksen, 2007, kap. 11). Imidlertid, forestillingen om å tilhøre en overlegen rase med siviliserende oppgaver og særskilte rettigheter i verden, preger all europeisk ekspansjon. Rasistiske holdninger og grove overgrep mot den afrikanske befolkningen var vanlig i kriser og krig fra alle kolonimaktenes side, sier forskningslitteraturen.

Ett forhold er forunderlig i denne sammenhengen. Tyskere og Tyskland som stat viste liten tilbakeholdenhet når det gjaldt å gjøre kjent på hvilken måte de mishandlet, torturerte og utryddet herero- og namabefolkningen. Det gjelder den offisielle generalstabshistorien om krigen som begynte å komme ut i 1906, og det gjelder beskrivelser i brev og memoarlitteratur og ikke minst innholdet $i$ et rikt arkivmateriale av fotografier. Det ble sendt postkort til og med av henrettelser. Manglende hemmelighold av misgjerningene sier noe om kolonialismens skamløshet og kan bare forklares med at afrikanerne var dehumanisert og ikke oppfattet som mennesker. De ble gjenstand for forskning og eksperimenter der et mål var å vise forskjellene på undermennesker og herrefolk. Boken viser til forskning som drøfter Hanna Arendts teser om forbindelse mellom rasisme, imperialisme og totalitære regimer, og mellom bestrebelsene på å skape et rom for det tyske "herrefolket" blant "undermenneskene" i Afrika og Det tredje rikes målsettinger om å skape "Lebensraum" og utslette "Untermenschen" i Øst-Europa under andre verdenskrig. 
Det klareste berøringspunktet mellom Namibia og Nazi-Tyskland var forestillingen om a tilhøre et Herrenvolk. Rasebiologer som hadde arbeidet med befolkningen i Namibia, fikk betydning for Hitler-styrets legitimering av erobring og okkupasjon i øst. En rasemessig underlegen fiende hadde ingen eksistensberettigelse. Tore viser hvordan oppfatningen om at det er "historiens lov" at "siviliserte" nasjoner har rett til å erobre og styre, er tankegods som ligger dypt forankret $i$ en felleseuropeisk sosialdarwinisme der indianere, maorier, aboriginere og enkelte grupper av folk i Afrika ble betegnet som "utdøende raser" (Eriksen, 2010, s. 216).

Tores monografi og artikler knyttet til Namibia, særlig underbygd av tysk forskningslitteratur, har pekt på konkrete og klare forbindelseslinjer, en kontinuitet, mellom tysk krigføring mot den afrikanske befolkningen i Tanzania og Namibia og naziregimets framferd på Østfronten under andre verdenskrig. Det er forbindelseslinjer fra de tyske "nyordningene" i kolonistyret i Namibia i 1905 til de antijødiske lovene under nazistyret i Tyskland i 1935 og helt fram til apartheidstyret i Sør- Afrika. Det har ført til en tyngde i hans produksjon i retning av spørsmålet om det finnes en Tysklands Sonderweg når det gjelder folkemord. Det er viktig for Tore å advare mot å presse fram en slik rettlinjet kontinuitet i tysk utvikling som bygger opp under forestillingen om en særegen tysk mentalitet (Eriksen, 2014). Namibia hører snarere til innenfor en felleseuropeisk ekspansjonshistorie. Den er en del av europeisk kolonihistorie heller enn forløper til Det tredje riket. Det vises til både fransk framferd i settlerkolonien Algerie, til kong Leopold $\mathrm{i}$ Kongo og til britene i det sørlige Afrika, til den britiske nedslaktingen av 10000 afrikanere med moderne maskingevær i slaget ved Omdurman i Sudan, og ikke minst til britisk styre i India. Lesningen av Tores framstilling av folkemordet i Namibia reiser imidlertid spørsmål ved om det er mulig for andre europeiske nasjoner å komme nær den ubegripelige bestialiteten som det tyske folkemordet i Namibia oppviser. $\AA$ si at tysk framferd i Namibia bare er en variant av europeisk framferd generelt, krever mer av sammenlignende forskning.

Europeerne og deres etterkommere $\mathrm{i}$ andre verdensdeler har ikke monopol verken på imperialisme eller rasisme. Dette sies i globalhistorien (Eriksen, 2010, s. 321), men dette temaet er svært lite utviklet når det gjelder "de andre". Tores forskning er i all hovedsak rettet mot å feie for egen dør. Hierarkiene av menneskeverd eksisterte også utenfor europeernes kultur og førte ofte til den mest brutale utbytting og nedvurdering av mennesker. Her ligger det en stor utfordring til ikke- europeiske forskere om å gå inn i den historiske virkeligheten som ligger utenfor all den oppmerksomheten som rettmessig har vært gitt til de mer tragiske virkningene av europeiske nasjoners frammarsj utenfor egne områder. Globalhistorien formidler at japanerne oppfattet kineserne og koreanerne som mindreverdige folkeslag. I omtalen av Kina er vi langt fra begrepet folkemord, til tross for at opprør og manglende styringskraft bidro til store natur- og sultkatastrofer ikke så ulikt det som skjedde i India under britisk styre. Japan innlemmet øya Hakkaido som et regulært fylke $i$ en avtale med Russland, samtidig med storstilt folkeflytting dit fra andre deler av Japan. Mellom 1850 og 1913 økte tallet på japanere fra 60000 til nærmere to millioner. Urbefolkningen ble utsatt for rasistisk diskriminering, men ordvalget i globalhistorien er forbausende mildt: De "ble trengt til side".

Tore Linné Eriksens bok om folkemordet i Namibia og hans artikler er en stor prestasjon når det gjelder å skaffe overblikk over et forskningsfelt der så mange forskere har bidratt, og når det gjelder å sammenfatte og presentere fortolkningene og det som underbygger dem, på en måte som gjør lesningen interessant og spennende. Det moralske engasjementet i framstillingen, som utvilsomt er til stede, svekker ikke det overbevisende inntrykket av faglig redelighet. 


\section{Arbeider av Tore Linné Eriksen som inngår i artikkelen:}

1969 Det politiske universitet. En bok om studenter og makt. Oslo:Gyldendal.

1974 Underutvikling En antologi om u-land og underutvikling i historisk perspektiv. Oslo: Gyldendal.

2007 Det tjuende århundrets første folkemord. Namibia 1903-1908.

Oslo: Unipub.

2008 Utslettelsen av Hererofolket i Namibia 1903-1908. I B. Hagtvet (Red.) Folkemordenes svarte bok. Oslo: Universitetsforlaget.

2009 Kolonialisme og folkemord: Riss av en globalhistorisk fagdebatt, Historisk Tidsskrift, 88(3), 399-428.

$2010 \quad$ Globalhistorie 1750 - 1900. En sammenvevd og delt verden. Oslo: Cappelen Akademisk Forlag.

2012 Det tyske folkemordet i Namibia - noen nye perspektiver, Etter Lemkin, $4(1), 13-22$.

2014 Kolonialisme og folkemord: Namibia som eksempel. I B. Hagtvet mfl. (Red.) Folkemordenes svarte bok. 2. utgave. Oslo: Universitetsforlaget. 